\title{
Wirtschaftspolitische Perspektiven für eine neue Bundesregierung
}

Vom 25. bis 27. Mai fand der achte New Paradigm Workshop des Forum New Economy statt. Unter dem Titel „Future of the German model II - Perspectives for the next government“ wurden verschiedene Herausforderungen diskutiert, die die deutsche Politik in der kommenden Legislaturperiode beschäftigen werden. Wir bereits beim ersten New Paradigm Workshop sollen auch diesmal ausgewählte Beiträge in einem Wirtschaftsdienst-Zeitgespräch zusammengefasst werden. Die Beiträge des vorherigen Workshops finden sich im Zeitgespräch der Ausgabe 100(10). Im aktuellen Heft werden Einblicke in neue Forschung auf den Gebieten Fiskalpolitik, Populismusforschung, Finanzmarktregulierung, Verteilungs- sowie Klimapolitik gewährt.

Die Definition einer zukunftsfähigen Finanzpolitik

Max Krahé, Insitut für Sozioökonomie der Universität Duisburg-Essen; Denkwerkstatt „Dezernat Zukunft“.

Philippa Sigl-Glöckner, Denkwerkstatt „Dezernat Zukunft“.

Wie kann Wirtschaftspolitik zur Eindämmung des Populismus beitragen?

Robert Gold, Institut für Weltwirtschaft in Kiel.

Krise und Reformbedarf der BaFin

Martin Hellwig, Max-Planck-Institut zur Erforschung von Gemeinschaftsgütern in Bonn.

Gerhard Schick, Verein Bürgerbewegung Finanzwende.

Ungleichheit der Haushaltsnettoeinkommen - Trends, Treiber, Politikmaßnahmen

Markus M. Grabka, DIW Berlin/SOEP.

Klimaschutz und der moderne Staat

Tom Krebs, Universität Mannheim.

Title: Economic Policy Perspectives for a New German Federal Government

Abstract: The eighth New Paradigm Workshop of the Forum New Economy took place from 25 to 27 May. Under the title "Future of the German model II - Perspectives for the next government", various challenges that will occupy German politics in the coming legislative period were discussed. As with the first New Paradigm Workshop, selected contributions will be summarised in a WirtschaftsdienstZeitgespräch. The contributions from the previous workshop can be found in the Zeitgespräch issue 100(10). The current issue provides insights into new research in the fields of fiscal policy, populism research, financial market regulation, distribution and climate policy JEL Classification: H30, G2O, D72 